\title{
Neuroprotective effects of 3,5-di-o-caffeoylquinic acid in vitro and in vivo
}

Junkyu Han ${ }^{1,2}$, Hiroko Isoda ${ }^{1,2^{*}}$

From 22nd European Society for Animal Cell Technology (ESACT) Meeting on Cell Based Technologies

Vienna, Austria. 15-18 May 2011

\section{Background}

Caffeoylquinic acid (CQA) derivatives are natural functional compounds isolated from a variety of plants and possess a broad range of pharmacological properties, including antioxidant, hepatoprotectant, antibacterial, antihistaminic, anticancer, and other biological effects [1]. Recently, it has been demonstrated that CQA derivatives possess neuroprotective effects in $\mathrm{A} \beta$-induced PC12 cell toxicity and in tetrahydropapaveroline (THP)induced C6 glioma cell death [2]. One of the animal models that is used to study $\mathrm{AD}$ and aging is the senescence-accelerated mouse (SAM). The SAM model was developed in 1981, which originally consisted of nine major senescence-accelerated-prone mice (SAMP) substrains and three major senescence-accelerated-resistant mice (SAMR) substrains, each of which exhibits the characteristic disorders.

\section{Methodology}

As in vitro experiment, the human neuroblastoma clonal SH-SY5Y cell were maintained at $37^{\circ} \mathrm{C}$ under $5 \% \mathrm{CO}_{2} /$ 95\% air. As in vivo experiment, the CQA-treated mice were orally administered with 3,5-di-O-CQA mixed with drinking water $(6.7 \mathrm{mg} / \mathrm{kg} \cdot$ day) for 1 month using oral administration tube and syringe. Proteomics analysis, real-time PCR, measurement of intracellular ATP content, Moris water maze were carried out to investigate the neuroprotective effect of CQA.

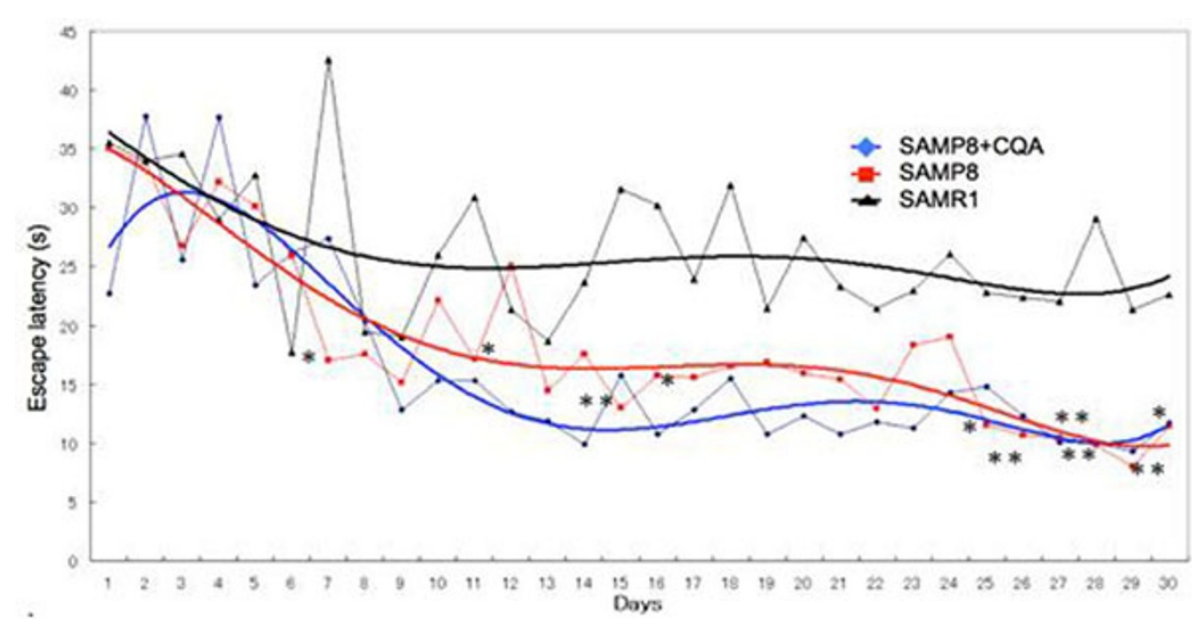

Figure 1 Effect of CQA on the spatial learning and memory of SAMP8 mice in MWM.

\footnotetext{
* Correspondence: isoda.hiroko.ga@u.tsukuba.ac.jp

'Graduate School of Life and Environmental Sciences, University of Tsukuba.

Tsukuba, Ibaraki 305-8572, Japan

Full list of author information is available at the end of the article
} 


\section{Results}

3,5-di-O-CQA had neuroprotective effect on $A \beta_{1-42}$ treated cells. The mRNA expression of glycolytic enzyme (phosphoglycerate kinase-1; PGK1) and intracellular ATP level were increased in CQA treated SHSY5Y cells. We also found that CQA administration induced the improvement of spatial learning and memory on SAMP8 mice, and the overexpression of PGK1 mRNA.

\section{Conclusion}

CQA has a neuroprotective effect on $\mathrm{A} \beta_{1-42}$ treated $\mathrm{SH}-$ SY5Y cells. The mRNA expression of glycolytic enzyme (PGK1) and the intracellular ATP level were increased in CQA-treated SH-SY5Y cells. We also found that CQA administration induced the improvement of spatial learning and memory on SAMP8 mice, and the overexpression of PGK1 mRNA level. These findings suggest that CQA has a neuroprotective effect through the induction of PGK1 expression and ATP production activation.

\section{Author details}

${ }^{1}$ Graduate School of Life and Environmental Sciences, University of Tsukuba. Tsukuba, Ibaraki 305-8572, Japan. ${ }^{2}$ Alliance for Research on North Africa (ARENA), University of Tsukuba. Tsukuba, Ibaraki 305-8572, Japan.

Published: 22 November 2011

\section{References}

1. Basnet P, Matsushige K, Hase K, Kadota S, Namba T: Four di-O-caffeoyl quinic acid derivatives from propolis. Potent hepatoprotective activity in experimental liver injury models. Biol Pharm Bull 1996, 19:1479-1484.

2. Soh Y, Kim JA, Sohn NW, Lee KR, Kim SY: Protective effects of quinic acid derivatives on tetrahydropapaveroline induced cell death in C6 glioma cells. Biol Pharm Bull 2003, 26:803-807.

doi:10.1186/1753-6561-5-S8-P20

Cite this article as: Han and Isoda: Neuroprotective effects of 3,5-di-ocaffeoylquinic acid in vitro and in vivo. BMC Proceedings 2011 5(Suppl 8): P20.
Submit your next manuscript to BioMed Central and take full advantage of:

- Convenient online submission

- Thorough peer review

- No space constraints or color figure charges

- Immediate publication on acceptance

- Inclusion in PubMed, CAS, Scopus and Google Scholar

- Research which is freely available for redistribution

Submit your manuscript at www.biomedcentral.com/submit
C Biomed Central 